strengthening of transatlantic relations, as well as on development co-operation.

Address: Klingelhöferstrasse 23, 10785 Berlin, Germany;

Rathausallee 12, 53757 Sankt Augustin, Germany.

Website: http://www.kas.de

Chairman: Dr Hans-Gert Pöttering.

\section{Lowy Institute for International Policy}

Founded 2003. Independent think tank that seeks to generate new ideas and dialogue on international developments and Australia's role in the world. Research ranges across all the dimensions of international policy debate in Australia-economic, political and strategic - and is not limited to a particular geographic region.

Address: 31 Bligh St., Sydney, NSW 2000, Australia.

Website: http://www.lowyinstitute.org

Executive Director: Michael Fullilove.

\section{National Bureau of Economic Research (NBER)}

Founded 1920. Private, non-profit, non-partisan research organization dedicated to promoting a greater understanding of how the economy works. Concentrates on four types of empirical research: developing new statistical measurements, estimating quantitative models of economic behaviour, assessing the economic effects of public policies and projecting the effects of alternative policy proposals.

Address: 1050 Massachusetts Ave., Cambridge, Massachusetts 02138-5398, USA.

Website: http://www.nber.org

President: James Poterba.

\section{Netherlands Institute of International Relations 'Clingendael'}

Non-profit, independent think tank for international relations. Identifies and analyses emerging political and social developments for the benefit of government and the general public. Programme concentrations: diplomatic studies; European studies; security and conflict; international energy.

Address: Clingendael 7, 2597 VH The Hague, Netherlands.

Website: http://www.clingendael.nl

Director: Prof. Dr Jaap (J. W.) de Zwaan.

\section{Overseas Development Institute}

Founded 1960. Independent think tank that focuses on international development and humanitarian issues. It aims to inform policy and practice that lead to the reduction of poverty, the alleviation of suffering and the achievement of sustainable livelihoods in developing countries.

Address: 11 Westminster Bridge Road, London SE1 7JD, UK.

Website: http://www.odi.org.uk

Director: Alison Evans.

\section{Peace Research Institute Oslo (PRIO)}

Founded 1959. Independent research institute that aims to promote peace through conflict resolution, dialogue and reconciliation, public information and policy-making activities. Research programmes: conflict resolution and peacebuilding; ethics, norms and identities; security programme. Two research centres: Centre for the Study of Civil War; Cyprus Centre.

Address: Hausmanns gate 7, 0186 Oslo, Norway.

Website: http://www.prio.no

Director: Kristian Berg Harpviken.

\section{Peterson Institute for International Economics}

Founded 1981. Private, non-profit, non-partisan research institution devoted to the study of international economic policy. Research encompasses country and regional studies, debt and development, globalization, international finance/macroeconomics, international trade and investment, and US economic policy.

Address: 1750 Massachusetts Ave., NW, Washington, D.C., 20036-1903, USA.

Website: http://www.iie.com

Chairman: Peter G. Peterson.

\section{Pew Research Center}

Founded 2004. Non-partisan, non-profit fact tank that provides information on the issues, attitudes and trends shaping America and the world through public opinion polling, demographic studies, media content analysis and other empirical social science research.

Address: 1615 L St., NW, Suite 700, Washington, D.C., 20036,

USA.

Website: http://pewresearch.org

President: Andrew Kohut.

\section{Polish Institute of International Affairs}

Founded 1999. Independent think tank that conducts original, policy-focused research and promotes the flow of ideas that inform and enhance the foreign policy of Poland. Programmes: international security; eastern and southeastern Europe; international economic relations and global issues; European Union; non-proliferation and arms control.

Address: 1A Warecka St., 00-950 Warsaw, Poland.

Website: http://www.pism.pl

Director: Marcin Zaborowski.

\section{RAND Corporation}

Founded in 1948 out of US military research and development during World War II by Douglas Aircraft. Independent, nonprofit organization dedicated to promoting scientific, educational and charitable purposes for the public welfare. Research areas include health, education, national security, international affairs, law and business, and the environment. Houses three federally funded research and development centres sponsored by the US defence department: the RAND Arroyo Center, providing research and analysis for the army; the RAND National Defense Research Institute; and RAND Project Air Force.

Address: 1776 Main St., Santa Monica, CA 90401-3208, USA.

Website: http://www.rand.org

President: James A. Thomson.

\section{Stockholm International Peace Research Institute (SIPRI)}

Founded in 1966 by the Swedish parliament. Independent international institute dedicated to research into conflict, 